https://doi.org/10.46344/JBINO.2020.v09i06.05

\title{
ACNE RELATED HETUS ACCORDING TO AYURVEDA IN MODERN ERA
}

\section{Dr.Jayashri Bharadia \& Dr. Om Prakash R Mundada}

Associate Professor, Dept Of Rognidan \&Vikruti Vignyan Dr.Vedprakash Patil Ayurved College \& Research Institute, Jalna,

Department of Urology, Mundada Urology Hospital, 6, Deogiri colony AIIMS ,Aurangabad,India

\begin{tabular}{|c|}
\hline ABSTRACT \\
\hline $\begin{array}{l}\text { Skin condition due to clogging of oil glands Characterised by comedowns, papules, cysts, } \\
\text { pustules, nodules and scars. Due to changed standard of living and heavy pollution this } \\
\text { problem is increasing in present era. } 80 \% \text { of individual are affected by Acne between } \\
\text { pubescence and } 30 \text { years of age, In the present paper we are discussing regarding the } \\
\text { acne related hetus in modern era of ayurveda }\end{array}$ \\
\hline
\end{tabular}

Keywords: acne,modern, ayurveda

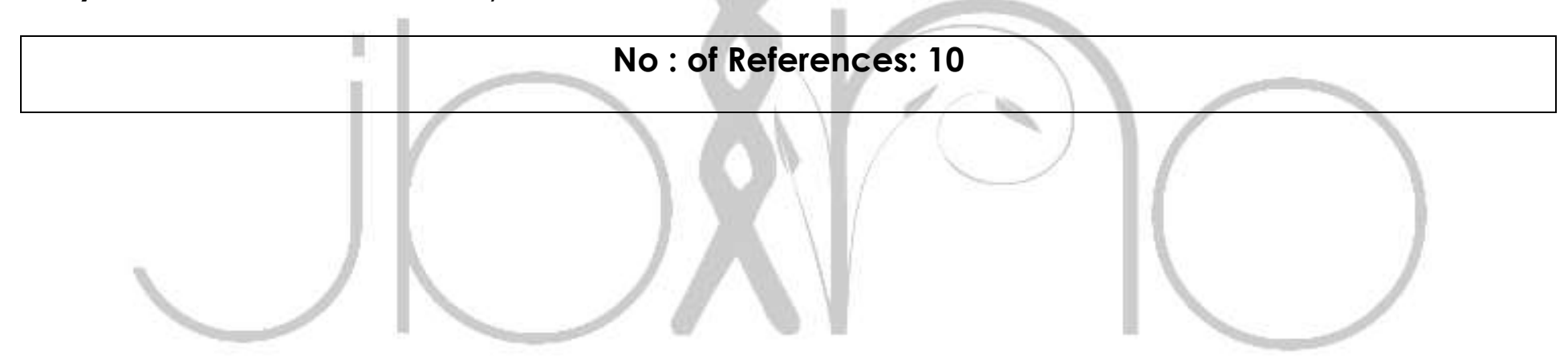




\section{INTRODUCTION}

Acne is the scourge of humanity and the travesty of youth. Acne is the most common skin disease facing humanity, it afflicts $89 \%$ of seventeen-year olds to some degree. In modern dermatology, a similar type of skin disorder or precisely sebaceous gland disorder named Acne vulgaris D Acne vulgaris is related to the pilosebaceous follicle. It is considered as adolescent disorder which is characterized by formation of open and closed comedones, papules, pustules, nodules and cysts. According to studies, several factors such as disturbed hormonal (androgen) production, excess sebum production, hyperkeratinisation are involved in pathophysiology of acne. Accumulation of excess sebum, epithelial cells and keratin obstruct the pilosebaceous follicle. This obstruction causes formation of a keratin plug and follicle swelling below skin surface, resulting in acne lesion.

Modern science has supposed the hormonal imbalance and blockage in the oil gland and ducts. Pitika, Saruja, Ghan, Medogarbha, Yuna Mukha these are the clinical manifestation in the Ayurveda. Most of the Acharya has mentioned in Vaman, Virechan, Nasya, Raktamokshan for Yuvana pidika or Mukhadushika along with Samana-chikitsa and local application. Shalmali, Dhanyaka, Vacha, Lodhra, Daruharidra, Manjishtha, Nimba, Khadira, Sariva, Guduchi, Methika, and
Zendu these are some herbal medicine and Lodhradi Lepa, Shalmali Kalkadi Lepa, Arjunadi Lepa, Jatiphaladi Lepa, Marichadi Lepa, Kumkumadi Taila, Majishthadi Taila, Haridradi Taila, Kanaka Taila and Sarshapa Taila these are some external application in the form of Taila and Lepa which are generally used in acne vulgaris.

Today's lifestyle, irregular diet and pollution are directly affecting the skin, causing many skin diseases and most common in them is Acne Vulgaris (Mukhadushika). Mukhadushika is explained by Sushruta under kshudra rogas [1] and is considered as swatantra vyadhi in the ayurvedic literature. It is characterized by shalmali kantaka sadrusha pidikas on face. It correlates to Acne Vulgaris explained in modern science.According to modern medical science, acne is a chronic inflammatory condition of the pilo sebaceous units, characterized by the formation of comedones, erythematic papules and pustules, less frequently nodules or cysts too.[2] It is the commonest dilemma associated with complexion and smoothness of skin. Sometimes leading to major skin problem, which is characterized by maculo, papulo, pustular eruptions on the skin especially on the face. A both male and female gender of adolescent age group is commonly affected. This disease is seen most from the cosmetic point of view than a medical one.The references for the disease of Acne Vulgaris (Mukhadushika) are well found in 
ayurvedic literature and is the most common problem that is met in general practice. [3] As it decreases the complexion and smoothness of the face, so this vyadi is known as Mukhadushika. [4] Face is the index of mind and a beauty. Cosmetic impact of deformities on the face is far reaching and in order to improve the complexion various soundarya vardhak dravyas were used in older times as similar to today's scenario.This created an interest to study the various aspects of the disease. Lepa procedure is described in many samhita, it harnesses the effect of mukhadushika as well as increase the mukhakanti. [5] Medicines in the form of a paste for external application are called lepas.

Lepas open the circulatory channels, facilitates the metabolic activity and improves the complexion of skin.

The pores are congested not only by sebum, but also by dry skin and dirt and a buildup of bacteria that worsen acne conditions. Acne lesions appear on the skin of the face, neck, shoulders and chest, and may be a cause of embarrassment because the age-group prone to acne break-outs are usually very conscious about their looks. If it is chronic in nature, it may lead to severe scarring.

Acne may be of the following types: black heads, white heads, pus-filled yellowish bumps or pustules, firm large swellings underneath the skin or nodules and cystic acne. Acne is called "Yuvana Pitaka" in
Ayurveda, which means boils affecting the youth.

Disturbed "Kapha", "Pitha" and "Rakhta" (blood) together produce boils, mostly on the face. As the Ayurvedic name suggests, these are present mostly in the age group of $15-25$ years, and in some, may extend till 35 years of age. Some physicians believe that disturbed "meda" or fat dhathu is also involved in the production of acne.

Ayurveda treats acne at the root of the problem and not at the surface.

Causes of Acne

1. Consumption of fatty and fried food and excess starch intake

2. Inadequate water intake

3. Unbalanced eating hours

4. Heredity

5. Nutritional deficiencies

6. Irritant cosmetics

7. Use of steroids

8. Hormonal imbalance

9. Chronic constipation

10. Inactivity

11. Improper skin cleansing

12. Stress

13. Inadequate sleep

14. Alcoholism 


\section{Tobacco intake}

16. Intake of caffeine.

Ayurvedic approach to acne

According to Ayurvedic concepts, bad food habits are the main cause of Yuvana Pidaka or Acne vulgaris.

This includes:

- $\quad$ Adhyashana - Consuming food at short intervals, due to which new food enters the body when the previous food is not digested

- Virudhashana - Consuming incompatible foods together such as fish and milk together, curds and milk together etc

- Vishamashana - Consuming food with disregard to the bodily cravings, such as eating when not hungry or fasting when hungry

On analysis of dosha involvement of yuvana pitaka, Vatha and Kapha dosha are found to be the causes. A pathological increase of raktha or blood and meda or fat dhatu can also cause yuvana pitaka.

Ayurveda believes that yuvana pitaka is a disease that is caused due to improper diet and other internal factors. Treatment Doshas involved are Kapha and Vatha. Vitiated Kapha blocks the normal excretory function of skin and the waste material stagnates inside, producing symptoms like itching, pustules and nodules formation.
Vitiated Raktha also gets stagnated and produces multiple eruptions, redness, raised local temperature, thick bloody discharge from the boils and abscess formation. Irritation, blackish discoloration and ugly scar formation are later contributed by Vitiated Vatha. Here the vitiated Doshas gets stagnated in the Srothas or Subtle channels of the body.

The etiopathology of the disease is due to vitiated Blood (Raktha Dushti) along with vitiated subtle channels to produce various symptoms of the disease. Thus to get permanent cure of the situation, this pathophysiology of the disease should be broken down. Treatment procedures are designed keeping in this mind.

Steaming and other heating procedures: This procedure is not advised during inflammatory stages. It is useful in removal of blockage of subtle channels or srothas.

- Vamana or medicated vomiting: Suitable medicines are orally given to induce vomiting. This procedure is very useful in removing blockage of subtle channels or Srothas of facial skin and whole body.

- Virechana or medicated purgation: It is a cleansing method, performed by giving bitter, astringent and sweet herbal purgatives which bring down abnormally increased Pitha principle and Raktha or blood dhathu. This procedure is beneficial in stages of inflammatory changes. 
- Nasya: Nasal administration of suitable medicine is beneficial in chronic clinical conditions of Acne.

- Raktamokshana (Blood letting): Is a well-accepted treatment for Vitiated Raktha Dosha. The circulating blood acts as a carrier of all vitiated doshas and responsible for the pathological changes resulting in diseases. The process of removing this stagnated blood i.e. Raktamokshana is useful in this condition.

- Leech application, Prachaana and Sira vyadha are the Para surgical methods for Rakthamokshana described by Sushruta. The affected tissue remains congested with the stasis of blood and blood letting improves microcirculation to tissues by removing this stagnated and vitiated blood.

\section{Conclusion}

Modern text described Acne vulgaris as a chronic inflammatory disorder of sebaceous follicles characterized by the formation of comedone, papules and pustules, less frequently nodules or cysts. All the Lepa and Pralapa are described as a Shamana-chikitsa Yuvana pidika while in severe cases Shodhana-chikitsa should be applied. The treatment should be changes according to the severity of acne. The Samhitas have pointed out Kapha, Vata, and Rakta as the causative factor of disease. Thus, Ayurveda help to enhance the charming face of the adolescence.

\section{REFERENCES}

API textbook of medicine, Edited by G. S. Sainanai fifth edition, reprint, published by association of physicians of India Bombay, $1994 ; 1266$.

2. Tahir CM. Pathogenesis of acne vulgaris: Simplified J. Pak Assoc Dermatol, 2010; 20: 93-7.

3. Collier CN, Harper JC, Cantrell WC, Wang W, Foster KW, Elewski BE. The prevalence of acne in adults 20 years and older J. Am Acad Dermatol, 2009; 58(1): 56-9.

4. Kumar S, Palbag S, Maurya SK, Kumar D. Skin care in Ayurveda: A literature review. International Research Journal of Pharmacy, 2103; 4(3): 1-3.

5. Bedi MK, Shenefelt PD. Herbal therapy in dermatology. Arch Dermatol, 2002; 138(2): 232-42.

6. Sharma A, Sharma PV. Sushruta Samhita. Varanasi: Chaukhambha Surbharati Prakashan, 2012; I: 559.

7. Gupta A, Upadhyaya Y. Ashtanga Hrudaya of Vagbhata. Varanasi: Chaukhambha Prakashan, 2012; 765.

8. Sushrutacharya, Sushruta Samhita with Nibandhasangraha Comentary by Dalhanacharya and Nyayachandrika Panjika of Gayadasacharyaa, kshudraroga nidan13-38 Edited by Yadavaji Trikamaji Acharya, and Naraya Ram Acharya Kavyatirtha, Reprint Edition, Chaukhamba 
Surabharati Prakashana, Varanasi, 2008; 287.

9. Kaviraj Ambikadutt Shastri, Sushruta Samhita edited with Ayurveda Tattva Sandipika, Vol 1st, Reprint edition, Chaukhambha Sanskrit Sansthan, Varanasi, Nidan Sthana, 2010; 13(37).

10. Dr. Brahamanand Tripathi. Astanga Hrdayam, Reprint edition, Chaukhamba Sanskrit Pratishthan, Delhi, Sutrasthana, 2009; 1 (25): 19. 